\title{
The Treatment of a Borderline Patient Complicated by Involvement with a Charismatic Religious Cult: A Case Report
}

\author{
Mark Miller, MD \\ Thomas Jefferson University Hospital
}

Follow this and additional works at: https://jdc.jefferson.edu/jeffjpsychiatry

Part of the Psychiatry Commons

Let us know how access to this document benefits you

\section{Recommended Citation \\ Miller, MD, Mark (1984) "The Treatment of a Borderline Patient Complicated by Involvement with a Charismatic Religious Cult: A Case Report," Jefferson Journal of Psychiatry. Vol. 2 : Iss. 1 , Article 9. DOI: https://doi.org/10.29046/JJP.002.1.005 \\ Available at: https://jdc.jefferson.edu/jeffjpsychiatry/vol2/iss1/9}

This Article is brought to you for free and open access by the Jefferson Digital Commons. The Jefferson Digital Commons is a service of Thomas Jefferson University's Center for Teaching and Learning (CTL). The Commons is a showcase for Jefferson books and journals, peer-reviewed scholarly publications, unique historical collections from the University archives, and teaching tools. The Jefferson Digital Commons allows researchers and interested readers anywhere in the world to learn about and keep up to date with Jefferson scholarship. This article has been accepted for inclusion in Jefferson Journal of Psychiatry by an authorized administrator of the Jefferson Digital Commons. For more information, please contact: JeffersonDigitalCommons@jefferson.edu. 


\title{
THE TREATMENT OF A BORDERLINE PATIENT COMPLICATED BY INVOLVEMENT WITH A CHARISMATIC RELIGIOUS CULT: A CASE REPORT
}

\author{
MARK MILLER, M.D.
}

\section{Introduction}

Although much has been written about cults in recent years, many questions remain. Do cults recruit subjects by brainwashing them or do individuals gravitate to cults to fulfill unmet needs? This paper will review some essential points of cult phenomena and discuss the treatment of one patient who was involved in a charismatic religious cult.

Lifton describes cults as the union of excessive character traits and grandiose ideology and finds their common features to be milieu control, mystical manipulation, a demand for purity with simplistic splitting of good and bad, an obsession with confession as vehicle for personal purification and self surrender, an aura of sacredness with prohibitions against questioning basic assumptions, an esoteric language that constricts individualism, the subordination of human experience to doctrinal claims and the creation of the right to dispense existence to the worthy (1). Saul Levine writes that the commonalities of cults far outweighed their differences:

They all have rituals, mystical presentations, a quasiintellectual theological tone, rigid hierarchy and rules, relative asceticism, high powered fund raising techniques or tithes and houses of worship. They vary in their flirtations with violence (zero to considerable), their total obeisance to an individual, their bizzare aspects, their relative prominence, their sense of persecution, their use of dishonest techniques, and their use of funds. What becomes clear, however, is that the particular content of the theology is never as important as the trappings, and certainly not as significant as believing, belonging, and the increase in self esteem (2).

Studies have shown those who join cults to be predominantly white, unmarried, in their early twenties, high school graduates and from intact families. Galanter in a study of the Moonies (3) found that $39 \%$ felt they had serious emotional problems in the past, $30 \%$ had sought professional help and $6 \%$ had been previously hospitalized. These numbers reflect twice the incidence of normal adolescents, according to Feinstein (4). Ungerleider et al (5) did psychological testing on 42 cult converts and found a mean overall WAIS score of 117 and MMPI profiles that were grossly normal.

Dr. Miller is a second-year resident in Psychiatry. 
In describing the cult effects on the converts, Clark wrote that:

The basic controls of the CNS seem to have altered; the menstrual periods may stop, or beard growth may be substantially slowed.

While in this state, personality changes drastically - a fact that often brings terrified parents into the physician's office. Converts often seem drab and dreamy outside the group, stereotyped, and somewhat expressionless when discussing anything other than their new experience. They lack mirth and richness of vocabulary. The devices of expression-irony, metaphor, and delight in the use of abstraction - are gone. Many converts report hallucinations, even olfactory ones, and experience group-validated delusions as well as nightmares. The sense of current history is quickly lost. If challenged they may become excited or even violent but at best answer difficult questions with memorized cliches.

Most converts are used for proselytizing and begging; they work extremely long hours to meet impossible goals. Some have reported sleeping less than four hours nightly for many years. They are often aware of their prior personality through dreams or shadowy memories (6).

Margaret Thaler Singer (7) interviewed 300 ex-cultists and found that many had sexual conflicts before joining and although a few reported enforced sex or group sex, most reported a decrease in sexual anxiety as sexual activity was highly restricted in order to keep members targeted on the work of the master.

Singer further comments that ex-cultists suffer lapses into altered states of consciousness:

From the time prospective recruits are invited to the cult's domicile-the ashram, our place in the country, the retreat, the family, the center - and after initiation, as well, they are caught up in a round of long, repetitive lectures couched in hypnotic metaphors and exalted ideas, hours of chanting while half-awake, attention-focusing songs and games, and meditating. Several groups send their members to bed wearing headsets that pipe sermons into their ears as they sleep, after hours of listening to tapes of the leader's exhortations while awake. These are all practices that tend to produce states of altered consciousness, exaltation, and suggestibility (7).

In addition to confusion and depression ex-cultists also suffer from indecesiveness, even toward simple tasks; and an uncritical passivity, where simple remarks are taken as commands after constant urging to surrender your mind, accept, melt, flow with it, don't question now, later you'll understand. Fund raising often produces guilt in ex-cultists for following cult rationalizations that deception was permissable for the greater good of the cult. Some solicitors were known to make $\$ 1500$ per day selling flowers and one testified to raising $\$ 250,000$ in 3 years ( 7 ).

In treating cult converts, deprogramming is usually the resort of desperate families attempting to rescue loved ones. It is described by Levine as usually involving 
coercion, detention, multiple deprogrammers, hyperstimulating methods, wearing down, and substitution of another (better) belief system. In its similarity to the coercive cult methods, Levine points out the legal, ethical and psychological issues raised by deprogramming and reports that it often fails (2).

Maleson (8) and Levine (2) in separate papers, write about the complexities of the role of the consulted psychiatrist as an advisor to families, an educator, and most importantly, a psychotherapist who may have little knowledge of cult phenomena. Levine finds that the best avenue for convincing the convert to leave a cult comes from within and resembles an adolescent identity crisis. Doubts raised by the patient are gently explored in a supportive manner to get the person in touch with their fears and anxieties. Confrontation regarding dogma is fruitless, usually producing packaged cult-counter-arguments. The real process of psychotherapy, says Levine, begins when the individual wrenches himself away from the cult and returns to his family or a semblance of his former life (2). Singer warns that:

Many therapists try to bypass the content of the experience in order to focus on long-term personality attributes. But unless he or she knows something of the events of the experience that prey on the former cultist's mind, we believe, the therapist is unable to open up discussions or even understand what is happening. Looking at the experience in general ways, he may think the young person has undergone a spontaneous religious conversion and may fail to be aware of the sophisticated, high-pressure recruitment tactics and intense influence procedures the cults use to attract and keep members. He may mistakenly see all the ex-cultist's behavior as manifestations of long-standing psychopathology (7).

\section{Case Report}

Sally, a 20 year old white female was involuntarily committed to a psychiatric hospital for a documented overdose of Dilantin. She had a previous psychiatric history of three inpatient hospitalizations following suicide attempts during which she was diagnosed according to DSM-III criteria as having a Borderline Personality Disorder.

Admission physical examination and laboratory profile were unremarkable. Medical history was significant only for a seizure disorder diagnosed when "black out spells" occurred after an auto accident as a child. No seizure activity had been witnessed for 10 years although she continued to take Dilantin.

On admission, Sally was guarded with isolated affect. She was dysphoric, though she denied suicidal ideation. She denied vegetative signs of depression and there was no evidence of formal thought disorder. Her sensorium was clear and her cognitive function was commensurate with her high school education. Sally's most striking feature was an intense confusion about the church.

Sally was the eldest of four girls. Her parents were divorced when she was in grade school. She had to assume many responsibilities at an early age while her mother worked to support the children in the South. The environment was often a violent one 
wherein the patient's mother once fired a pistol at a boyfriend. Sexual activity between mother and various men was frequently witnessed. Sally later reported being sexually molested regularly by an uncle over a period of months, at age ten.

At age twelve, for economic reasons, Sally was sent to live with her paternal grandmother in a northern city, a move described by Sally as a relief from sexual harassment. When Sally was thirteen years old, her mother and three sisters died in a trailer fire. One of the mother's boyfriends was tried for arson but no conviction resulted. Shortly thereafter, the patient sought outpatient psychiatric treatment. She managed to graduate from high school and held odd jobs while living with her aging grandmother. Her father, an alcoholic, was seen infrequently and was verbally abusive. During late adolescence, erratic psychiatric follow-up took place. Three months prior to this hospitalization Sally's grandmother died. While the remaining relatives argued over the settlement of the grandmother's estate, Sally was approached by a member of The Church of Bible Understanding, a cultlike organization similar to the Moonies. This organization, according to The Philadelphia Inquirer (September 1982), was responsible for the beating of a 13 year old boy who was the son of the leader, Stewart Traill (9).

The patient stated that certain church members had been good to her and that she was amazed by their inner peacefulness and their answers to metaphysical questions regarding God and his plan for the universe. Simultaneously, however, the patient expressed concern about church motives in controlling every aspect of her life.

Sally described a well organized indoctrination with idealized promises of conflict-free living attainable by accepting, without question, church teachings, which included a mixture of interpretations of bible passages and rock group lyrics. Printed material, e.g., The Gospel of John in Colors and excerpted Pink Floyd lyrics was distributed. Other methods of indoctrination included repetitive hypnotic chanting, sleep and nutritional deprivation, a unique vocabulary, and a ranking system by which converts began as lambs, then became sheep and finally shepherds. Sally voluntarily transferred the contents of her entire bank account to the church for its mission in the third world. Converts were threatened with damnation and group reprisal for noncompliance. Sally reported that she was difficult to convert and was thus subjected to hours of seclusion in the resurrection room with a continuous background of taped chanting.

\section{Hospital Course}

Sally's hospital course was a stormy one marked by two suicide attempts, the exacerbation of pre-cult psychopathology, relentless attempts by the church to lure her back, and the slow process of reestablishing autonomy outside the cult. Early in her hospitalization, Sally was visited by church members who proselytized to other patients and had to be asked to leave. They reportedly warned Sally that they considered her to be on vacation and that if forced to remain she should opt for going to Jesus and suggested a method of suicide using the ward electrical sockets. With Sally's 
permission, it was decided to screen all visitors, phone calls, and mail, although attempts to contact Sally continued throughout her four month hospitalization. Excerpts from mail that the patient received included: "You need to trust that he is very pleased that you gave your life to him and he is not going to let you go;" also: "my sister moonshine has made me relize (SIC) a true sister of the wind becomes a woman of the earth, PS: I feel you in the Radio-Sing out."

Psychotherapy initially centered on non-confrontative ego support. Answers to questions regarding whether the church was right or not were sought by Sally with strong intensity of affect. Over several weeks, a gradual decline in the use of packaged cult jargon was observed, along with a growing suspicion on the part of the patient that the church decrees were not consistent with her Protestant upbringing. Past memories evoked in the early part of therapy produced a regression evident in both the patient's artwork, which was filled with dismembered burning bodies; and in graphic violent nightmares. Suicide was seen by the patient as potential relief from these disturbing images.

Sally had periods of productive ward activity and was well liked by the staff, many members of which developed rapport with her. Two four-week trials of adequately dosed antidepressants produced little benefit. After a suicide attempt by hanging, various theraputic changes were instituted including the addition of a female cotherapist. All issues of therapeutic potential were channelled by the staff to the primary therapist in order to avoid confusion. Seclusion, used liberally, in combination with neuroleptic medication, was found to be helpful in damping the intensity of disturbing thoughts. The suicide attempts coincided with the revelations that (1) the patient had been repeatedly examined and raped in the cult in ritualistic fashion, eventually resulting in a pregnancy that was aborted under church direction, and (2) that she had not willingly taken an overdose of Dilantin, but that church members had forced her to take her own Dilantin in an attempt to kill her.

Sally eventually claimed that she found relief once her troubling secrets were shared, even though references to them brought signs of affective instability. The patient would often leave therapy sessions to regain composure before continuing. The co-therapists agreed that there had been a catharsis but it was clear that the patient faced years of working through her conflicts, and would remain a serious risk for suicide. Our therapeutic efforts attempted to align with the nondestructive part of her ego by encouraging her to separate violent impulses from actual behavior. We also encouraged her to utilize the external supports of seclusion and prn neuroleptics to endure difficult periods. Sally was eager to solve all of her problems, to find a job and get on with the rest of her life; an eagerness tempered by the realistic hope that the resolution of conflicts could result from long-term psychotherapy and that small gains could produce progress. Setbacks were to be expected, tolerated, and lost progress regained. Metaphors like turtle-steps (of progress) were found to be helpful.

After four months of therapy, Sally reached a level of stability marked by a decrease in dysphoria and a shift in thinking to constructive planning. Due to her continued risk for suicide, the patient was transferred to a long-term hospital. 


\section{Discussion}

Many people are vulnerable to indoctrination by cults. As physicians, we encounter the effects of cult experience in our patients along with their inherent psychopathology. Sally lies on the severe end of the Borderline spectrum as evidenced by her identity disturbance, her lability of mood, her tendency to over-idealize, her intense anger and ambivalence and her multiple suicide attempts. The deterioration of the patient's support system apparently increased her vulnerability to the seductive allure of easy answers provided by the church, which served as an external ego for the organization of her life experience through rigid rituals and ideological constructs.

I must confess a strong personal bias against exploitative cults, particularly since their success rests, in part, on the destructive application of the same principles that psychiatry is based on. Having stated this, I must also point out how this bias initially interfered with therapy. James Masterson (10) writes that "... the single most difficult skill to acquire in psychotherapy with borderline patients is the ability to recognize and control one's own identification with their projections ..." Indeed, my initial reaction led me to see Sally as a victim, producing rescue fantasies of infiltrating and exposing the cult (at the very least calling "60 Minutes"!). Realizing that Sally needed the church as much as they wanted her allegiance was important in forming a balanced therapeutic stance.

The initial question raised by this paper was whether cults psychologically kidnap their converts or whether converts need what the cult offers and are for this reason drawn toward them. Both factors were operative in the described case report but each factor could, in itself, lead to involvement in cults. Destructive cults operate on the principle that those with ideological hunger and some sense of dissatisfaction with their life are vulnerable to indoctrination (producing capable fund raisers). These are most often late adolescents struggling with issues of identity. While it is true that the character traits of many patients predispose them to the influence of cults at any age, it is a mistake to attribute all cult involvement to pre-cult psychopathology.

Psychiatrists have an obligation to be informed about coercive cults so that we may educate those who seek our help. We have a moral obligation to encourage the public exposure of destructive cult methods and to take a stand against their mind controlling exploitation.

\section{REFERENCES}

1. Lifton, R: Thought Reforms and the Psychology of Totalism. New York, WW Norton and Co., 1956

2. Levine, SV: The role of psychiatry in the phenomenon of cults, Can J Psychiatry 24: 593-603, 1979

3. Galanter, M et al: The "Moonies": a psychological study of conversion and membership in a contemporary religious sect. Am J Psychiatry 136: 165-170, 1979

4. Feinstein, SC: The Cult Phenomenon: Transition, Repression, and Regression. The University of Chicago, 1980 
5. Ungerleider, $\mathrm{T}$ et al: Coercive persuasion (brainwashing), religious cults, and deprogramming. Am J Psychiatry 136: 279-282, 1979

6. Clark, G: Cults. JAMA 242: 279-281, 1979

7. Singer, MT: Coming out of the cults. Psychol Today 12: 72-82, 1979

8. Maleson, F: Dilemmas in the evaluation and management of religious cultists. Am $J$ Psychiatry 138: 925-929, 1981

9. Odom, M: “4 in Religious Group Guilty of Assault,” Philadelphia Inquirer, Sept 24, 1982

10. Masterson, J: Psychotherapy of the Borderline Adult. New York, Brunner/Mazel, 1976

11. Galanter, $\mathbf{M}$ et al: Charismatic religious sects and psychiatry: An overview. Am J Psychiatry 139: 1539-1548, 1980

12. Deutsch, A: Tenacity of attachment to a cult leader: A psychiatric perspective. Am $J$ Psychiatry 137: 1569-1573, 1980

13. Spero, M: Psychotherapeutic procedure with religious cult devotees. J Nerv Ment Dis 170: 332-344, 1982 